\title{
RESPONSES OF NEMATODES TO UNGULATE HERBIVORY ON BLUEBUNCH WHEATGRASS AND IDAHo Fescue IN Yellowstone National PaRK
}

\author{
EVELYN MERRILL $\downarrow$ JON HAK, $\downarrow$ NANCY STANTON \\ DEPARTMENT OF ZOOLOGY AND PHYSIOLOGY \\ UNIVERSITY OF WYOMING $\uparrow$ LARAMIE
}

\begin{abstract}
$\uparrow \quad$ ABSTRACT
Above- and belowground biomass of Idaho fescue Festuca idahoensis and bluebunch wheatgrass Agropyron spicatum and nematode densities under these plant species were sampled during the growing season inside and outside a 2-year old exclosure on Crystal Bench in Yellowstone National Park. Early in the growing season, grazed plants of both species had lower shoot and root biomass than ungrazed plants. Standing biomass of grazed plants was equal to ungrazed plants at the end of the growing season.

Densities/g root biomass of phytophagous and bacterial feeding nematodes were higher under grazed than ungrazed plants of both plant species only early in the growing season. Foliar concentrations of nitrogen in grazed plants were higher than ungrazed plants but there was no difference in root nitrogen between grazed and ungrazed plants.
\end{abstract}

The effects of ungulate grazing on the Northern winter range of Yellowstone National Park has recently received considerable attention (Frank 1990, Coughenour 1991, Singer 1992, Wallace submitted). Early interest in this topic centered around the question to cull or not to cull elk in the Park. However, as the concepts of "maintaining ecological processes" (Houston 1982) and "ecosystem management" (Keiter 1991) have gained acceptance in Park management, understanding the dynamics and interactions of a broader array of herbivores inhabiting the Park have become increasingly important. In this paper, we describe the results of a study which focused on the effects of aboveground herbivory on nematode density and trophic structure.

Root-feeding nematodes are major herbivores in other grassland systems and may consume twice as much biomass as aboveground consumers (Ingham and Detling 1984, Stanton 1988). Houston (1982) reported that nothing is known about the effects of nematodes on the native grasses of the northern range especially in combination with aboveground grazers. We hypothesized that if spring grazing is intense, grazed plants would initially show a decline in root growth and phytophagous nematodes. Cessation of root growth is a common response of plants to grazing and may occur within the first 2-24 hours (Hodgkinson and Baas Becking 1977). Evidence to date supports the idea that phytophagous nematode densities are highest under moderate levels of grazing and low under heavily grazed and ungrazed plants (Stanton 1983, Stanton et al. 1984, Seastedt 1985, Seastedt et al. 1988). Because senescing roots, subsequent to grazing, provide increased substrates for decomposers, we also hypothesized that microbial activity and nitrogen mineralization should increase (Stanton et al.1984). As a result, we expected to detect an increase in microbial feeding nematodes.

As root regrowth occurred, we expected phytophagous nematodes to increase. However, we 
predicted that populations would not reach levels found under ungrazed plants because plants in grazed areas experience higher levels of nitrogen mineralization (Holland and Detling 1990) than ungrazed plants and may produce proportionally fewer numbers of root hairs (nutrient absorption organs) which serve as feeding sites for nematodes. Because of reduced densities of phytophagous nematodes and increased mineralization rates under grazed plants, we expected grazed plants to recoup their losses rapidly. The net result we predicted would be no detectable differences in aboveground or belowground biomass during years of normal rainfall.

Thus, our study addressed 3 null hypotheses. First, root and shoot biomass of grazed and ungrazed plants will be similar at the end of the growing season. Second, density of phytophagous and microbial feeding nematodes will not differ between grazed and ungrazed plants. Finally, nitrogen concentration of roots and aboveground foliage will not be higher in grazed than in ungrazed plants. We focused our attention on bluebunch wheatgrass Agropyron spicatum and Idaho fescue Festuca idahoensis because of their importance as winter range forages and because Mueggler (1975) reported that bluebunch wheatgrass was more sensitive and recovered more slowly to heavy clipping than Idaho fescue.

\section{STUDY AREA}

Our study site is located in the upper portion of the northern winter range near Crystal Creek at an elevation of approximately $1900 \mathrm{~m}$. The site is a flat bench created by glacial deposits. Soils at the site were described in an earlier study as sandy loam having a bulk density of $1.31 \mathrm{~g} / \mathrm{cc}, \mathrm{pH}$ of 6.30, organic matter content of $5.4 \%$ and nitrogen content of $0.2 \%$ (Frank 1990: Table 2). Vegetation at the site is characterized as a xeric grassland dominated by bluebunch wheatgrass, Idaho fescue, junegrass Koeleria cristata, needle and thread grass Stipa comata, lupine Lupinus sericeus and horsebrush Tetradymia canescens (Wallace submitted). This study occurred in the second growing season after the extreme drought and fires of 1988 but the site was not burned during the 1988 fires. Data from Mammoth, Wyoming indicate that precipitation was average during most of the 1989 growing season. The exceptions were higher than average precipitation in early May 1989, and below average precipitation in September (Frank 1990: Fig. 2). In 1990, January-March precipitation at Mammoth, Wyoming was lower than average, April and May precipitation was at or above normal, and June-August precipitation was below normal.

Although the site is grazed year-round by large ungulates, primarily elk Cervus elaphus, bison Bison bison and pronghorn Antilocapra americana, it receives its greatest use by all species in the winter and spring (Frank 1990).

\section{METHODS}

We collected 6-10 randomly selected plants of bluebunch wheatgrass and Idaho fescue from outside and inside a large exclosure (15 x $15 \mathrm{~m})$ that was established in August of 1987 and had not received any ungulate grazing for more than 2 years (Frank 1990). Plants were collected with a soil corer (diameter $4.8 \mathrm{~cm}$, depth $10 \mathrm{~cm}$ ). Because of the rocky, shallow soil, sampling deeper than $10 \mathrm{~cm}$ was precluded. Smolik (1974) found that in the shortgrass prairie, the top $10 \mathrm{~cm}$ contains about $50 \%$ of the nematodes. Cores were kept cool in an ice chest while transported to the laboratory where they were refrigerated until processing.

Aboveground biomass was clipped at $2 \mathrm{~cm}$ and standing dead and green biomass were separated, dried at $40^{\circ} \mathrm{C}$ for at least 48 hours and weighed. The soil cores were suspended in cold water and the soil gently washed from the roots. The suspension was sieved first to remove plant tissue (sieve \#18) and then to remove nematodes (sieve \#325). Roots were hand-sorted while suspended in water and crowns, including the aboveground biomass to $2 \mathrm{~cm}$, were cut from the roots. Roots and crowns were dried at 40 degrees $C$ for at least 48 hours and weighed. We made no attempt to distinguish between dead and live roots. We used dry weights in our analysis because dry root weight and ash-free weight is highly correlated (Stanton 1983: $r=0.94$ ). Nitrogen content of roots, crowns and aboveground green biomass, was analyzed using standard macro-kjeldahl techniques.

Four additional cores were collected, 2 within in the large exclosure and 2 in grazed areas to determine soil moisture. Soil moisture was determined as the percent difference in total core 
weight before and after drying at 60 degrees $\mathrm{C}$ to a constant weight.

Nematodes were extracted on Baermann funnels for $48 \mathrm{hrs}$ (Christie and Perry 1951). Nematode abundance and trophic category were determined by counting the number of individuals present in $21-\mathrm{ml}$ subsamples of a $30 \mathrm{ml}$ suspension as described by Smolik (1974). Numbers of nematodes were corrected for extraction efficiencies which averaged $92 \%$ for bacterial feeders and $93 \%$ for plant feeders. In the analysis, Monohysteridae were classified as bacterial feeders.

Normal distribution of our data sets were tested using a Lilliefors test (Lilliefors 1967). Only data on nitrogen concentration were normally distributed. Differences in biomass of plant parts from different grazing treatments were tested using a Mann-Whitney $U$ test. Logarithmic transformations of nematode counts provided normally distributed data. Differences in nitrogen concentration and nematode densities of grazed and ungrazed plants within approximately monthly sampling period were tested using a t-test. We used a significance level of $p=0.05$ unless otherwise indicated.

\section{$\downarrow \quad$ RESULTS}

\section{PLANT BIOMASS}

Standing dead litter of ungrazed bluebunch wheatgrass was greater than grazed plants at the beginning of the growing season (Table 1). This difference remained significant but narrowed during the growing season as dead plant material from previous years growth fragmented, decomposed, or was eaten by small herbivores. Litter within ungrazed Idaho fescue plants was also significantly greater than in grazed plants until the end of the growing season.

\begin{tabular}{|c|c|c|c|c|c|c|c|c|}
\hline & & & & & & & & \\
\hline & May & June & July & Sept & May & June & July & Sept \\
\hline $\begin{array}{c}\text { Standing dead } \\
\text { Grazed } \\
\text { Ungrazed }\end{array}$ & $\begin{array}{l}0.00^{\circ} \\
0.94^{\circ}\end{array}$ & $\begin{array}{l}0.02^{\circ} \\
0.26^{\circ}\end{array}$ & $\begin{array}{l}0.05^{\alpha} \\
0.19^{\circ}\end{array}$ & $\begin{array}{l}0.06^{4} \\
0.45^{4}\end{array}$ & $\begin{array}{l}0.00^{\circ} \\
0.17^{\circ}\end{array}$ & $\begin{array}{l}0.01^{\mathrm{D}} \\
0.04^{6}\end{array}$ & $\begin{array}{l}0.03^{*} \\
0.06^{\circ}\end{array}$ & $\begin{array}{l}0.10 \\
0.24\end{array}$ \\
\hline $\begin{array}{c}\text { Green biomass } \\
\text { Grazed } \\
\text { Ungrazed }\end{array}$ & $\begin{array}{l}0.23^{6} \\
0.94^{*}\end{array}$ & $\begin{array}{l}0.25^{\circ} \\
0.68^{\circ}\end{array}$ & $\begin{array}{l}1.51 \\
1.53\end{array}$ & $\begin{array}{l}1.79 \\
0.68\end{array}$ & $\begin{array}{l}0.20^{\circ} \\
0.85^{\circ}\end{array}$ & $\begin{array}{l}0.15 \\
0.25\end{array}$ & $\begin{array}{l}0.30 \\
0.44\end{array}$ & $\begin{array}{l}1.26 \\
0.45\end{array}$ \\
\hline 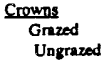 & $\begin{array}{l}2.29 \\
3.14\end{array}$ & $\begin{array}{l}1.66 \\
1.37\end{array}$ & $\begin{array}{l}1.54 \\
1.26\end{array}$ & $\begin{array}{l}1.36 \\
1.28\end{array}$ & $\begin{array}{l}2.61 \\
3.02\end{array}$ & $\begin{array}{l}1.00 \\
1.11\end{array}$ & $\begin{array}{l}0.70 \\
0.94\end{array}$ & $\begin{array}{l}1.37 \\
1.03\end{array}$ \\
\hline $\begin{array}{l}\text { Beels } \\
\text { Grazed } \\
\text { Ungrazed }\end{array}$ & $\begin{array}{l}0.98^{\circ} \\
1.51^{\circ}\end{array}$ & $\begin{array}{l}1.05 \\
0.97 \\
\end{array}$ & $\begin{array}{l}0.92 \\
0.83 \\
\end{array}$ & $\begin{array}{l}1.90 \\
1.81 \\
\end{array}$ & $\begin{array}{l}1.02^{\circ} \\
1.38^{\circ}\end{array}$ & $\begin{array}{l}0.89^{\circ} \\
1.48^{\circ}\end{array}$ & $\begin{array}{l}0.68 \\
0.91 \\
\end{array}$ & $\begin{array}{l}1.62 \\
1.00 \\
\end{array}$ \\
\hline
\end{tabular}

Aboveground green biomass of ungrazed plants was approximately 3-4 times greater than grazed plants in May (Table 1). This difference disappeared in Idaho fescue by June and in bluebunch wheatgrass by July so that aboveground standing biomass of grazed plants of both species equaled that of ungrazed plants. In September, standing biomass of plants subjected to ungulate grazing was equal to plants that had been excluded from grazing in both species. Crown biomass was not different between grazed and ungrazed plants at any sampling date (Table 1 ).

In May, root biomass averaged $35 \%$ and $26 \%$ lower in grazed plants of bluebunch wheatgrass and Idaho fescue, respectively (Table 1). These differences disappeared by early June in bluebunch wheatgrass but lingered into mid-July in Idaho fescue. By September root reserves were generally replenished.

\section{NITROGEN CONCENTRATIONS}

Nitrogen concentration of green aboveground biomass was significantly greater in plants outside the exclosure than inside the exclosure in both months sampled (Table 2). However, nitrogen concentration of root biomass was similar in plants from inside and outside the exclosure.

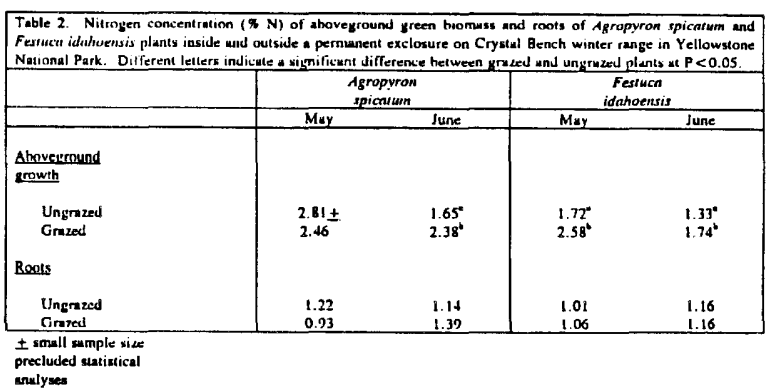

\section{NEMATODE DENSITIES}

Abundance of nematodes followed a bimodal distribution with a peak in May when soil moisture was high (22\%) and a nadir in July when soil moisture was at its lowest (2\%) (Table 3). In May, bacterial feeding nematodes were significantly higher under plants of both species that were open to grazing than those not open to grazing. This difference persisted into June under Idaho fescue plants but not under bluebunch wheatgrass plants. Similarly, densities of phytophagous nematodes were higher under grazed plants than ungrazed plants and these differences persisted into June only under Idaho fescue plants. 


\begin{tabular}{|c|c|c|c|c|c|c|c|c|}
\hline & & & & & & & & \\
\hline & May & June & July & Sept & May & June & July & Sept \\
\hline $\begin{array}{l}\text { Plant parasites } \\
\text { Ungrazed } \\
\text { Grazed }\end{array}$ & $\begin{array}{c}966^{\circ} \\
202^{\circ}\end{array}$ & $\begin{array}{l}105 \\
100\end{array}$ & $\begin{array}{l}58 \\
42\end{array}$ & $\begin{array}{l}52 \\
56\end{array}$ & $\begin{array}{l}76^{\circ} \\
346^{\circ}\end{array}$ & $\begin{array}{l}59^{\circ} \\
167^{\circ}\end{array}$ & $\begin{array}{l}34 \\
37\end{array}$ & $\begin{array}{l}77 \\
59\end{array}$ \\
\hline $\begin{array}{l}\text { Bacterial feeders } \\
\text { Ungrazed } \\
\text { Grazed }\end{array}$ & $\begin{array}{l}814^{2} \\
991^{\circ}\end{array}$ & $\begin{array}{l}488 \\
285\end{array}$ & $\begin{array}{l}285 \\
249\end{array}$ & $\begin{array}{l}354 \\
281\end{array}$ & $\begin{array}{c}856^{\circ} \\
1319^{\circ}\end{array}$ & $\begin{array}{l}236^{2} \\
539^{\circ}\end{array}$ & $\begin{array}{l}205 \\
286\end{array}$ & $\begin{array}{l}420 \\
782\end{array}$ \\
\hline
\end{tabular}

\section{$\downarrow \quad$ DISCUSSION}

Both this study and others (Coughenour 1991, Singer 1992) have documented an 4-10 fold increase in plant litter in areas on the northern range fenced from grazing and an increase in bareground in grazed areas. Despite early seasonal differences in green biomass, by the end of the growing season green biomass of grazed plants of both plant species equaled that of plants in the ungrazed areas. Frank (1990) found that grazing stimulated aboveground primary production by $36 \%$ at the site in 1989 , a year of average or above average precipitation. Bluebunch wheatgrass appeared to take longer to replace aboveground biomass than Idaho fescue but this was not true for root biomass.

Our results indicate that aboveground grazing by ungulates facilitates feeding by some belowground taxa. Plant parasitic nematodes increased rather than decreased with grazing as we had hypothesized. Seastedt et al. (1988) hypothesized that belowground herbivores may increase after moderate levels of aboveground grazing because root quality counteracts the absolute decline in root resources. We found no difference in root nitrogen between grazed and ungrazed plants but did not examine changes in other parameters such as soluble carbohydrates, secondary plant compounds, or fine root hairs. Damage to root tips also may stimulate lateral root growth which may support high densities of nematodes (Hogger 1972, Rebois and Johnson 1973, Torrey 1976).

The high densities of microbial feeding nematodes found under grazed plants in May (both species) and June (Idaho fescue only) may be related to root mortality. Dying roots provide a short-term source of carbon for microbes and a prey base for microherbivorous nematodes. We suggest that increased microbial biomass and activity increased nitrogen mineralization. Subsequently grazing by nematodes and protozoa release $\mathrm{N}$ to plants that would otherwise have become inaccessible in the microbial biomass.

In summary, results of the study supported our first null hypothesis that root and shoot growth of grazed and ungrazed plants would be similar at the end of the growing season. However, we rejected the remaining 2 hypotheses that nematode densities and foliar nitrogen concentration were similar under grazed and ungrazed plants, at least early in the growing season when soil moisture was high. We suggest that aboveground grazing by ungulates influences nitrogen dynamics belowground and that microbial feeding nematodes play an important role in nitrogen turnover. However, the relationship between above- and belowground grazers remains unclear.

\section{$\downarrow \quad$ ACKNOWLEDGEMENTS}

We wish to thank Francis Singer, John Varley, and Rich Klukas of Yellowstone National Park Service, and Mark Boyce and the late George Menkens from University of Wyoming-National Park Service Research Center for their administrative support. Jack Norland, Cathy Wilson, Renee Schenewerk and Sarah Reitz provided assistance with field work and data collection. We thank Doug Frank for maintaining his exclosures. This study was funded through the University of Wyoming-National Park Service Research Center and the University of Wyoming Research Office.

\section{LITERATURE CITED}

Christie, J. R. and V. G. Perry. 1951. Removing nematodes from soil. Proc. Helminthol. Soc. Washington 18:106-108.

Coughenour, M. B. 1991. Biomass and nitrogen responses to grazing of upland steppe on Yellowstone's northern winter range. J. Appl. Ecol. 28: 71-82.

Frank, D. A. 1990. Interactive ecology of plants, large mammalian herbivores and drought in Yellowstone National Park. Ph.D. Dissertation. Syracuse University, Syracuse, N.Y. 123 pp. 
Hodgkinson, K. C. and H. G. Baas Becking. 1977. Effect of defoliation on root growth of some arid zone perennial plants. Aust. J. Agric. Res. 29:31-42.

Hogger, C. 1972. Effect of Tichodorus christiei inoculum density and growing temperature on growth of tomato roots. J. Nematol. 4:66-67.

Holland, E. A. and Detling, J. K. 1990. Plant response to herbivory and belowground nitrogen cycling. Ecology 71: 1040-1049.

Houston, D. B. 1982. The northern Yellowstone elk. Macmillan Publ. Co. New York. 473.

Ingham, R. E. and J. K. Detling. 1984. Plantherbivore interactions in a North American mixed-grass prairie. III. Soil nematode populations and root biomass on Cynomys ludovicianus colonies and adjacent uncolonized areas. Oecologia (Berl.) 63:307-313.

Keiter, R. B. 1991. An introduction to the ecosystem management debate. Pages 3-18 In The greater Yellowstone Ecosystem: redefining America's wilderness heritage, eds. R.B. Keiter and M.S. Boyce. Yale Univ. Press.

Lilliefors, H. W. 1967. On the KolmogorovSmirnov test for normality with mean and variance unknown. J. Amer. Statistical Assoc. 64:399-402.

Mueggler, W. F. 1975. Rate and pattern of vigor recovery in Idaho fescue and bluebunch wheatgrass. J. Range Manage. 28: 198-204.

Rebois, R. V. and W. C. Johnson. 1973. Effect of Rotylenchulus reniformis on yield and nitrogen, potassium, phosphorus and amino acid content of seed of Glycene max. J. Nemotol. 5:1-6.
Seastedt, T.R. 1985. Maximization of primary and secondary productivity by grazers. Am. Nat. 126:559-564.

R. A. Ramundo, and D. C. Hayes. 1988. Maximization of densities of soil animals by foliage herbivory: empirical evidence, graphical and conceptual models. Oikos 51:243-248.

Singer, F. J. 1992. Effects of elk and other ungulate grazing on the northern winter of Yellowstone National Park In Effects of grazing by native ungulates on Yellowstone's northern range. F. J. Singer and J. D. Varley, eds. Nat. Park Service Rep. to Congress. Yellowstone National Park, Yellowstone Park, WY.

Smolik, J. D. 1974. Nematode studies at the Cottonwood site. IBP. Grassland Biome.Tech. Rep. No. 251. Nat. Resour. Ecol. Lab. CSU, Ft. Collins, Co.

Stanton, N.L. 1983. The effect of clipping and phytophagous nematodes on net primary production of blue grama, Bouteloua gracilis. Oikos 40:249-257.

D. Morrison, and W. Laycock. 1984. The role of plant parasitic nematodes in blue grama die-off. J. Range Management 37:447-450.

1988. The underground in grasslands. Ann. Rev. Ecol. Syst. 19:573-589.

Torrey, J. G. 1976. Root hormones and plant growth. Ann. Rev. Physiol. 27:435-459.

Wallace, L. submitted, Grazing and competition in montane grasslands. Ecology。 